\title{
Lactic acid bacteria inhibit the growth of Vibrio parahaemolyticus and the invasion of Caco-2 cells
}

\author{
Ying-An Lua ${ }^{\mathrm{a}}$, Pei-Pei Lin ${ }^{\mathrm{b}}$, You-Miin Hsieh ${ }^{\mathrm{a}}$, Cheng-Chih Tsai ${ }^{\mathrm{c}, *}$ \\ ${ }^{a}$ Department of Food and Nutrition, Providence University, Taichung City 43301 Taiwan \\ b Department of Culinary Arts, Hungkuo Delin University of Technology, New Taipei City 23654 Taiwan \\ c Department of Food Science and Technology, HungKuang University, Taichung City 43302 Taiwan
}

*Corresponding author, e-mail: tsaicc@sunrise.hk.edu.tw

Received 8 Jun 2018

Accepted 3 Dec 2019

\begin{abstract}
Vibrio parahaemolyticus is a major cause of foodborne illnesses worldwide resulting from the consumption of raw seafood. Lactic acid bacteria (LAB) influence the health of human intestine by enhancing immune system function and acting as antibacterial agents. In this study, 7 LAB (PM12, PM14, PM63, PM212, PM222, BCRC14735, and BCRC17010) were found to adhere to the intestinal epithelial Caco-2 cells as well as to inhibit the growth of $V$. parahaemolyticus. The viability of Caco- 2 cells infected with $V$. parahaemolyticus was tested by the lactate dehydrogenase (LDH) assay. Our results indicated that PM12, PM14, PM63, PM212, BCRC14735 and BCRC17010 inhibited V. parahaemolyticus BCRC10806 and BCRC12865. While, PM222 could exhibit the maximum comparative adherence ability to Caco-2 cells. The LDH assay results revealed that 5 LAB (PM12, PM14, PM63, PM212, and PM222) significantly decreased the cytotoxicity induced by the V. parahaemolyticus BCRC10806 and BCRC12865 after $2 \mathrm{~h}$ of incubation. In the competition assay, the prevention group demonstrated inhibitory effects against two $V$. parahaemolyticus. Besides, we noted that these 7 LAB inhibited the invasion of V. parahaemolyticus into the Caco-2 cells.
\end{abstract}

KEYWORDS: Vibrio parahaemolyticus, lactic acid bacteria, adherence, invasion

\section{INTRODUCTION}

Vibrio parahaemolyticus, a gram-negative bacterium, produces more than three types of hemolysin virulence factors ${ }^{1}$. Its prevalence is widespread across oceans, coasts, estuaries, and swamps worldwide, and it coexists with plankton and large marine animals as well as with other living beings and inanimate objects ${ }^{1}$. The major regions where poisoning by $V$. parahaemolyticus is observed are Japan and East Asian countries, although the frequency is lower in some of the Asian countries possibly due to differences in the form of aquatic product consumption ${ }^{2}$. V. parahaemolyticus is mainly detected in raw fish and shellfish. The common sources of infection are clams, oysters, crabs, shrimps, and lobsters. V. parahaemolyticus occurrence in fresh fish and shellfish during the summer is more than $90 \%$, and the consumption of these fishes causes food poisoning when the number of bacteria counts on the fish exceed $10^{5} \mathrm{CFU} / \mathrm{g}$.

In recent years, $V$. parahaemolyticus possessing a type III secretion system (T3SS) has been found. In vitro studies have confirmed that T3SS induces cytotoxicity in Caco-2 cells ${ }^{3}$. Park et $\mathrm{al}^{4}$ reported that T3SS1 produces cytotoxins in human cells, whereas T3SS2 produces endotoxins in animal infection models and cytotoxins in the gut. Additionally, Zhang et $\mathrm{al}^{5}$ indicated that T3SS2 is involved in the invasion of $V$. parahaemolyticus into human cells. Akeda et $\mathrm{al}^{6}$ demonstrated that some isolated $V$. parahaemolyticus not only produces toxins but also invades intestinal cells. V. parahaemolyticus was revealed to invade Caco-2 cells associated with Rho, Rac, and Cdc42 proteins ${ }^{7}$. Typical clinical symptoms of $V$. parahaemolyticus-induced food poisoning are acute dysentery and abdominal pain accompanied by diarrhea, nausea, vomiting, fever, shivering, and watery stools ${ }^{8,9}$; also, some patients complain of mucus or blood in their stools, which lowers their blood pressure and may eventually result in unconsciousness, convulsions, paleness, and even death ${ }^{10,11}$.

Satish Kumar et al $^{12}$ reported that Lactobacillus plantarum AS1 can inhibit the adsorption of Vibrio spp. by HT-29 intestinal cells via its antimicrobial activity by producing bacteriocins, lactic acid, and 
exopolysaccharides. Yang et $\mathrm{al}^{13}$ also demonstrated that LAB can delay the intestinal fluid accumulation and villus damage caused by $V$. parahaemolyticus in mice. The authors further reported that strains with stronger adsorption ability are more protective than those with stronger antibacterial ability, indicating that the adsorption capacity is more important ${ }^{14}$. Shirazinejad et $\mathrm{al}^{15}$ soaked fresh shrimp in $3.0 \%$ lactic acid for $10 \mathrm{~min}$ and observed that it effectively inhibited the growth of pathogenic bacteria. The cell-free supernatant (LBP102) of L. plantarum NTU 102 was found to be effective against $V$. parahaemolyticus ${ }^{16}$.

The present study aimed to screen for $L A B$ from pickled vegetables and from the Bioresource Collection and Research Center (BCRC; Hsinchu, Taiwan) and evaluate their effects on the growth inhibition and invasion of $V$. parahaemolyticus into Caco-2 epithelial cells.

\section{MATERIALS AND METHODS}

\section{Bacteria and cell culture condition}

A total of 386 strains, comprising $86 \mathrm{LAB}$ purchased from BCRC, and $300 \mathrm{LAB}$ isolated from pickled vegetables were used in this study. LAB were cultured in Lactobacillus MRS broth (Difco; Detroit, Michigan, USA) supplemented with $0.05 \%(\mathrm{w} / \mathrm{v})$ L-cysteine and incubated at $37^{\circ} \mathrm{C}$ for $20 \mathrm{~h}$. The cultured cells were then transferred into MRS broth containing $25 \%$ (v/v) glycerol and frozen at $-80^{\circ} \mathrm{C}$. V. parahaemolyticus purchased from BCRC was cultured in Tryptic soy broth (TSB) and Tryptic soy agar (TSA) supplemented with $2.5 \%(\mathrm{w} / \mathrm{v}) \mathrm{NaCl}$ at $37^{\circ} \mathrm{C}$ for $18 \mathrm{~h}$. V. parahaemolyticus was then transferred into TSB supplemented with $2.5 \% \mathrm{NaCl}$ and $25 \%$ glycerol and then frozen at $-80^{\circ} \mathrm{C}$.

Human rectal cancer cells (Caco-2) purchased from BCRC were subsequently cultured in Dulbecco's modified Eagle medium supplemented with $10 \%(\mathrm{v} / \mathrm{v})$ fetal bovine serum (FBS) and $1 \%(\mathrm{w} / \mathrm{v})$ nonessential amino acid transferrin. All media and supplement were obtained from GIBCO BRL Laboratories (NY, USA).

\section{The inhibition zone of LAB}

LAB ( $1 \mathrm{ml}$ ) were cultured for $20 \mathrm{~h}$ and centrifuged at $8000 \mathrm{rpm}$ for $10 \mathrm{~min}$, then filtered through a $0.22-\mu \mathrm{m}$ filter to obtain the supernatant, which was stored at $-20^{\circ} \mathrm{C}$ until further use. In this study, V. parahaemolyticus incubated overnight in a $2.5 \%$ NaCl-supplemented TSB were diluted to approximately $10^{7} \mathrm{CFU} / \mathrm{ml}^{17,18}$ and spread on the agar. A sterile 1-ml tip was used to make a 9-mm-diameter well in the agar plate. LAB supernatant $(100 \mu \mathrm{l})$ was transferred into the well, and the plate was incubated at $4^{\circ} \mathrm{C}$ for $2 \mathrm{~h}$, followed by incubation at $37^{\circ} \mathrm{C}$ for $12 \mathrm{~h}$ and a measurement of the inhibition zone diameter.

The bacteriostasis ability of LAB was categorized into 4 grades depending on the size of the zone of inhibition. The zone of inhibition was defined according to the zone diameter as:,$- \leqslant 11 \mathrm{~mm} ;+$, $12-16 \mathrm{~mm} ;++, 17-22 \mathrm{~mm}$; and,$+++ \geqslant 23 \mathrm{~mm}^{17}$. Also, the LAB and its supernatant were adjusted to $\mathrm{pH} 7.2$ and heated at $100^{\circ} \mathrm{C}$ for $15 \mathrm{~min}$. They were then diluted twice, and the inhibition zone test was performed to assess the ability of the LAB to inhibit V. parahaemolyticus.

\section{Antimicrobial testing of LAB and V. parahaemolyticus co-culture}

Based on the method of Varma et $\mathrm{al}^{18}$, the antibacterial activity was performed by culturing $1 \mathrm{ml}$ of $V$. parahaemolyticus $\left(10^{5} \mathrm{CFU} / \mathrm{ml}\right), 1 \mathrm{ml} \mathrm{LAB}$ $\left(10^{7} \mathrm{CFU} / \mathrm{ml}\right), 4 \mathrm{ml} \mathrm{TSB}$, and $4 \mathrm{ml}$ of $2.5 \% \mathrm{NaCl}-$ containing MRS broth. Above mediums were mixed (total $10 \mathrm{ml}$ ) afterwards then culture for $4 \mathrm{~h}$ at $37^{\circ} \mathrm{C}$. After $4 \mathrm{~h}$, the cells were centrifuged at $1000 \times g$, washed twice with phosphate-buffered saline (PBS), serially diluted, and then plated on a Petri dish with thiosulfate-citrate-bile salts-sucrose (TCBS) agar. The bacteria were then incubated overnight at $37^{\circ} \mathrm{C}$; then, the number of $V$. parahaemolyticus colonies was counted. V. parahaemolyticus colonies appeared blue-green on differential TCBS agar medium. The survival of $V$. parahaemolyticus was calculated using the following equation:

Survival $(\%)=\frac{\text { No. after co-culture with LAB }}{\text { No. after co-culture with MRS }} \times 100$

\section{Antibiotic susceptibility of V. parahaemolyticus}

V. parahaemolyticus was diluted to $10^{7} \mathrm{CFU} / \mathrm{ml}$. The cells were stained with a sterile cotton swab and spread uniformly on an approximately 4-mmthick Mueller-Hinton agar plate. Once the bacterial suspension dried, sterile antimicrobial disc (Disc; Oxoid) were placed on the surface of the agar plate using sterile forceps and gently pressed to ensure that it completely contacted on the agar plate surface and to ensure error-free measurement of the inhibition zone. The antimicrobial discs were placed at $\geqslant 1.4 \mathrm{~cm}$ away from the edge of the dish and at intervals of $\geqslant 2.2 \mathrm{~cm}$ between the discs. After incubation at $37^{\circ} \mathrm{C}$ for $14-16 \mathrm{~h}$, the clear zone 
around the discs was measured. The following 9 antimicrobial discs were used in the experiment: ampicillin $(10 \mu \mathrm{g})$, kanamycin $(30 \mu \mathrm{g})$, tetracycline (30 $\mu \mathrm{g})$, penicillin G (10 units), neomycin $(15 \mu \mathrm{g})$, streptomycin $(10 \mu \mathrm{g})$, gentamicin $(30 \mu \mathrm{g})$, chloramphenicol $(30 \mu \mathrm{g})$, and spiramycin $(100 \mu \mathrm{g})$.

\section{Competitive adhesion assay of LAB and V. parahaemolyticus on Caco-2 cells}

The methods of Gueimonde et $\mathrm{al}^{19}$ and Satish Kumar et $\mathrm{al}^{12}$ were adopted, albeit with some modifications, for the competitive adhesion assay. Briefly, $1 \mathrm{ml}$ each of LAB $\left(10^{9} \mathrm{CFU} / \mathrm{ml}\right)$ and V. parahaemolyticus $\left(10^{7} \mathrm{CFU} / \mathrm{ml}\right)$ were mixed and subjected to the following conditions: initial centrifugation at $9500 \times \mathrm{g}$ for $10 \mathrm{~min}$ and discarding of the supernatant, addition of $1 \mathrm{ml}$ PBS and vortex, final centrifugation and removal of supernatant, washing of cells, and addition of a $1 \mathrm{ml}$ cell culture medium.

Subsequently, $1 \mathrm{ml}$ of the Caco-2 cell suspension was added to each 24-well culture plate (at a cell concentration of $2 \times 10^{5}$ cells $/ \mathrm{ml}$ ), followed by uniform mixing and incubation at $37^{\circ} \mathrm{C}$ for 2 days in a $5 \% \mathrm{CO}_{2}$ incubator (Forma Direct Heat $\mathrm{CO}_{2}$ Incubator, Thermo). After confirmation of complete cell attachment, the old medium was aspirated and the cells were washed twice with PBS. Next, $800 \mu 1$ of the fresh medium, $100 \mu 1$ each of LAB (for the control group, $100 \mu \mathrm{l}$ of cell culture medium), and $V$. parahaemolyticus were added, followed by centrifugation of the 24-well culture plate at $90 \times g$ for 2 min at $37^{\circ} \mathrm{C}$ under $5 \% \mathrm{CO}_{2}$. The culture fluid was aspirated again and the cells were carefully washed twice with PBS. Cells were subsequently diluted by adding $1 \mathrm{ml}$ of $0.25 \%(\mathrm{w} / \mathrm{v})$ trypsin/EDTA and then scraped using a sterile tip. To these cells, $9 \mathrm{ml}$ of PBS was added, followed by serial dilution, pour plating via the TCBS method, and incubating overnight at $37^{\circ} \mathrm{C}$; subsequently, the V. parahaemolyticus colonies were counted. V. parahaemolyticus grew on the differential medium TCBS agar as blue-green colonies. The survival of $V$. parahaemolyticus was calculated using the following equation:

$$
\text { Survival }(\%)=\frac{\text { No. in the presence of LAB }}{\text { No. in the control group }} \times 100
$$

The competitive adhesion assay was conducted in three experimental modes: (1) the exclusion group, the LAB was added for $1 \mathrm{~h}$, after addition of $V$. parahaemolyticus for $1 \mathrm{~h}$; (2) the competition group, LAB and $V$. parahaemolyticus were added simultaneously for adhesion and incubated for $1 \mathrm{~h}$; and (3) the displacement group, V. parahaemolyticus was added before the addition of LAB (for adhesion for $1 \mathrm{~h}$ ) and incubated for $1 \mathrm{~h}$.

\section{Assay of the inhibition of the invasion of V. parahaemolyticus into Caco-2 cells by LAB}

Based on the method of Akeda et al ${ }^{6,7}$ and Zhang et $\mathrm{al}^{5}, 1 \mathrm{ml}$ of the cell suspension was added into each 24-well culture plate (cell concentration adjusted to $2 \times 10^{5}$ cells/ ml), mixed uniformly, and incubated at $37^{\circ} \mathrm{C}$ under $5 \% \mathrm{CO}_{2}$ for 2 days. After confirming that the cells were completely attached, the old medium was aspirated, added $200 \mu \mathrm{l}$ of glutaraldehyde for $10 \mathrm{~min}$, and washed twice with PBS. Next, $800 \mu \mathrm{l}$ of fresh medium, $100 \mu \mathrm{l}$ each of LAB $\left(10^{9} \mathrm{CFU} / \mathrm{ml}\right.$ ) (or control group: $100 \mu \mathrm{l}$ of fresh medium), and $100 \mu \mathrm{l}$. parahaemolyticus $\left(10^{7} \mathrm{CFU} / \mathrm{ml}\right)$ were added. Then centrifuged the resulting mixture at $1000 \mathrm{rpm}$ for $2 \mathrm{~min}$ and incubated at $37^{\circ} \mathrm{C}$ under $5 \% \mathrm{CO}_{2}$ for $3 \mathrm{~h}$. After carefully washing twice with PBS, $1 \mathrm{ml}$ of kanamycin containing $100 \mu \mathrm{g} / \mathrm{ml}$ (cell medium without FBS) was added to each well, followed by incubation at $37^{\circ} \mathrm{C}$ under $5 \% \mathrm{CO}_{2}$ for $1 \mathrm{~h}$ and washing twice with PBS. After $10 \mathrm{~min}$ of $0.1 \%(\mathrm{v} / \mathrm{v})$ Triton X-100 treatment, the lysate was transferred into $9 \mathrm{ml}$ PBS and serially diluted. Suitable dilutions were then plated on a Petri dish with TCBS agar. Following overnight incubation, the number of $V$. parahaemolyticus colonies was counted. V. parahaemolyticus grew on differential TCBS agar medium as blue-green colonies. The $V$. parahaemolyticus inhibition was calculated as follows:

$$
\text { Inhibition }(\%)=\left[1-\frac{\text { No. in the presence of LAB }}{\text { No. in control group }}\right] \times 100
$$

\section{Lactate dehydrogenase (LDH) analysis}

LDH exists in the cytoplasm. When cell damage occurs, LDH will release. Quantification of the amount of LDH can allow the determination of the degree of cell injury.

LDH was measured according to the method of Matlawska-Wasowska et $\mathrm{al}^{20}$ using the CytoScanTM LDH Cytotoxicity Assay Kit (G-Biosciences, USA). In brief, $100 \mu \mathrm{l}$ of a Caco-2 cell suspension was added to each 96-well culture plate (cell concentration was adjusted to $10^{4}$ cells $/ 100 \mu \mathrm{l}$ ), uniformly mixed, and then incubated at $37^{\circ} \mathrm{C}$ under $5 \% \mathrm{CO}_{2}$ for $24 \mathrm{~h}$. After confirmation of complete cell attachment, the medium was aspirated and washed twice with PBS, and $100 \mu \mathrm{l}$ each of $V$. parahaemolyticus $\left(10^{6} \mathrm{CFU} / \mathrm{ml}\right)$ and $\mathrm{LAB}\left(10^{8} \mathrm{CFU} / \mathrm{ml}\right)$, were added. After incubating for 1 or $2 \mathrm{~h}$ under $5 \% \mathrm{CO}_{2}$, the cell suspension was centrifuged at $1100 \mathrm{rpm}$ for $5 \mathrm{~min}$. The supernatant $(50 \mu \mathrm{l})$ was pipetted into a fresh 96-well plate, and $50 \mu \mathrm{l}$ of the substrate mix was 
added to each well, followed by incubation in the dark at $37^{\circ} \mathrm{C}$ for $20 \mathrm{~min}$. Then, $50 \mu \mathrm{l}$ of the stop solution was added to each well and the absorbance was read at $490 \mathrm{~nm}$. Cytotoxicity was calculated as follows:

Cytotoxicity $(\%)=\left[\frac{\text { Experimental }- \text { Control }}{\text { Lysis }}\right] \times 100$

\section{Statistical analysis}

Statistical analysis was performed using the Statistical Package for the Social Science (version 20.0) software package. The experimental results were analyzed by one-way analysis of variance and expressed as mean \pm SD. The differences between the mean values of each experimental group were tested using the Duncan's Multiple Range Test, $p<0.05$ was considered as statistical significance.

\section{RESULTS AND DISCUSSION}

LAB inhibited the growth of V. parahaemolyticus

In this study, the zone of inhibition was calculated by the diffusion method to analyze $386 \mathrm{LAB}$ sourced from BCRC and plant pickles. Table 1 shows that 25 strains of LAB supernatant inhibited $V$. parahaemolyticus BCRC10806 and BCRC12865 with + inhibitory capacity, and the maximum inhibition zone observed was $15 \mathrm{~mm}$. In our previous study, we indicated that LAB can inhibit $V$. parahaemolyticus-mediated inflammatory responses and can also effectively inhibit the growth of $V$. parahaemolyticus in seafood products ${ }^{21}$.

Effect of LAB cultured medium and different treatments of the supernatant on the inhibitory capacity of $V$. parahaemolyticus

From this study, 10 LAB (PM12, PM14, PM63, PM80, PM81, PM114, PM120, PM206, PM212, and BCRC17010) showed first-class inhibitory effect on V. parahaemolyticus BCRC10806 and BCRC12865, with a maximum inhibition zone of $13 \mathrm{~mm}$ (Table 2).

Nine strains of LAB (PM14, PM81, PM84, PM114, PM119, PM120, PM206, PM212, and BCRC17010) showed a first-class inhibitory effect on V. parahaemolyticus BCRC10806 after heating at $100^{\circ} \mathrm{C}$ for $15 \mathrm{~min}$. The inhibition zone of PM212 reached $15 \mathrm{~mm}$ (Table 2). Four strains of LAB (PM81, PM120, PM206, and BCRC17010) showed a first-class inhibitory effect against $V$. parahaemolyticus BCRC12865, with an inhibition zone of $12 \mathrm{~mm}$ (Table 2). Only one strain (PM63) showed a first-class inhibitory effect on $V$. parahaemolyticus
BCRC10806 after the LAB supernatant was heated at $100^{\circ} \mathrm{C}$ for $15 \mathrm{~min}$ (Table 2). The above results demonstrated a decrease in the bacteriostatic capacity of heated LAB or even the loss of bacteriostatic effect. It was found that the antibacterial capacity of $L$. rhamnosus supernatant heated at $90^{\circ} \mathrm{C}$ for 20 min decreased, suggesting that the proteins of the antibacterial ingredients may be denatured by heating ${ }^{22}$.

Gopal et $\mathrm{al}^{23}$ revealed that the lactic acid secreted by LAB and the small peptides possess a synergistic effect on bacteriostasis. Therefore, the small peptide molecules of LAB showed effective bacteriostasis under acidic condition. Here, when the LAB and supernatant were adjusted to $\mathrm{pH} 7.2$, the inhibitory activity for $V$. parahaemolyticus was lost (Table 2). Also, two dilutions of LAB and supernatant revealed no inhibition for the two strains of $V$. parahaemolyticus (Table 2). Kaur et al ${ }^{24}$ reported that the culture supernatant of lactobacilli inhibited biofilm formation in Vibrio cholerae by more than $90 \%$, but neutralization of the $\mathrm{pH}$ of culture supernatant also abrogated their antimicrobial ability against $V$. cholera.

\section{LAB and V. parahaemolyticus co-culture for antibacterial test}

LAB $\left(10^{8} \mathrm{CFU} / \mathrm{ml}\right)$ and $V$. parahaemolyticus $\left(10^{6} \mathrm{CFU} / \mathrm{ml}\right)$ were diluted to a $100: 1$ ratio in a culture tube for the inhibition test. Table 3 shows that the residual rates of $V$. parahaemolyticus decreased for the 15 strains of LAB co-cultured with the two strains of $V$. parahaemolyticus (BCRC10806 and BCRC12865) for $4 \mathrm{~h}$. Additionally, after $2 \mathrm{~h}$ of co-culture, the survival of $V$. parahaemolyticus decreased significantly; after $3 \mathrm{~h}$, the survival was approximately zero, indicating that the growth of $V$. parahaemolyticus was effectively inhibited by the cell culture supplementation with LAB. According to literature, Hwanhlem et $\mathrm{al}^{25}$ showed that LAB can completely inhibit the growth of $V$. parahaemolyticus within $24 \mathrm{~h}$.

\section{Antimicrobial disc sensitivity test}

The 10 antimicrobial discs used in this test revealed that two V. parahaemolyticus strains were susceptible to ampicillin and penicillin $G$ (Table 4). The screened LAB supernatants repressed the inhibitory activity of $V$. parahaemolyticus BCRC10806 in a manner similar to that of the neomycin and streptomycin antimicrobial discs, with an inhibition zone diameter of 12-16 mm; also, LAB supernatants inhibited the invasion of $V$. parahaemolyticus BCRC12865 
Table 1 Agar diffusion test showing the antagonistic activity of the spent culture supernatants (SCS) of LAB against V. parahaemolyticus.

\begin{tabular}{|c|c|c|c|}
\hline & \multirow{2}{*}{ Strain } & \multicolumn{2}{|c|}{ Inhibition zone $^{\dagger}$} \\
\hline & & 10806 & 12865 \\
\hline BCRC & 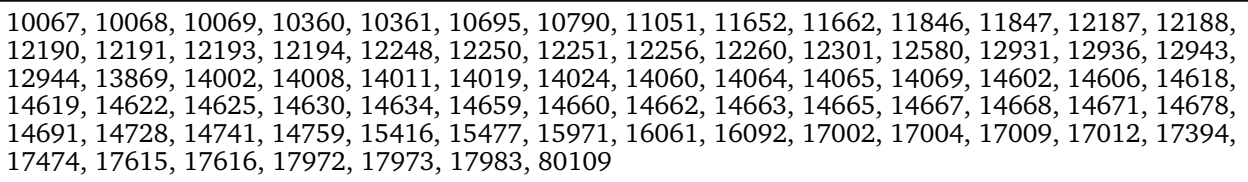 & - & - \\
\hline PM & $\begin{array}{l}1-11,13,15-62,64-70,72-77,79,82,83,85-100,102-113,115,116,118,121-123,126-133, \\
135-151,155,163,165,167,170-174,177,180-187,190,192-196,199,200,202,203,207-211 \\
213-218,220,221,223,225-228\end{array}$ & - & - \\
\hline FM & $1-58,60-66,68-71$ & - & - \\
\hline $\begin{array}{l}\text { BCRC } \\
\text { PM }\end{array}$ & $\begin{array}{l}17614 \\
71,78,101,117,125,134,164,166,205\end{array}$ & - & $\begin{array}{l}+ \\
+\end{array}$ \\
\hline $\begin{array}{l}\text { BCRC } \\
\text { PM } \\
\text { FM }\end{array}$ & $\begin{array}{l}10696,14080,14677,14735,16000,17010 \\
124,152,153,156,158,198,201 \\
67\end{array}$ & $\begin{array}{l}+ \\
+ \\
+\end{array}$ & $\begin{array}{l}- \\
- \\
-\end{array}$ \\
\hline $\begin{array}{l}\text { BCRC } \\
\text { PM } \\
\text { FM }\end{array}$ & $\begin{array}{l}12574,14084 \\
12,14,63,80,81,84,114,119,120,157,160,175,176,178,188,191,197,204,206,212,222,229 \\
59\end{array}$ & $\begin{array}{l}+ \\
+ \\
+\end{array}$ & $\begin{array}{l}+ \\
+ \\
+\end{array}$ \\
\hline
\end{tabular}

† The inhibition zone: $-\leqslant 11 \mathrm{~mm} ;+, 12-16 \mathrm{~mm} ;++, 17-22 \mathrm{~mm}$; and +++, $\geqslant 23 \mathrm{~mm}$.

in a manner similar to that of the erythromycin, streptomycin, and spiramycin discs, with an inhibition zone diameter of 12-13 mm (Table 4). Increasing numbers of antibiotic-resistant pathogens is an important issue in the world. However, the application of probiotics to inhibit the growth of Vibrio spp. might be a good method for preventing the pathogen and may also reduce its chances of antibiotic resistance ${ }^{26}$.

\section{LAB adhesion to Caco-2 intestinal epithelial cells}

According to Pedersen and Tannock ${ }^{27}$, LAB can attach more than 15 bacterial cells to pig porcine squamous epithelial cells, evidencing the adhesion properties of this strain. As shown in Fig. 1, a total of 14 LAB (BCRC14677, BCRC14735, BCRC17010, PM12, PM14, PM63, PM80, PM81, PM84, PM114, PM119, PM120, PM206, and PM222) could adhere to Caco-2 cells. Our results showed that PM222 possessed the highest adhesion ability, averaging 34 cells/Caco-2 cell, while the other 7 strains (PM80, PM84, PM114, PM119, PM120, PM206, and BCRC17010) were found to adhere at a rate of more than 15 cells/Caco-2 cell (Fig. 1).

Several in vitro assays employ lactobacilli adsorption assays on intestinal cell lines such as human rectal cancer cells (Caco-2 and HT-29) ${ }^{23,28,29}$. Caco- 2 cells isolated from human with rectal cancer reportedly exhibited in vitro morphology, functional differentiation, and mature gut characteristics such as functional brushlike microvilli ${ }^{30}$; thus, Caco-2

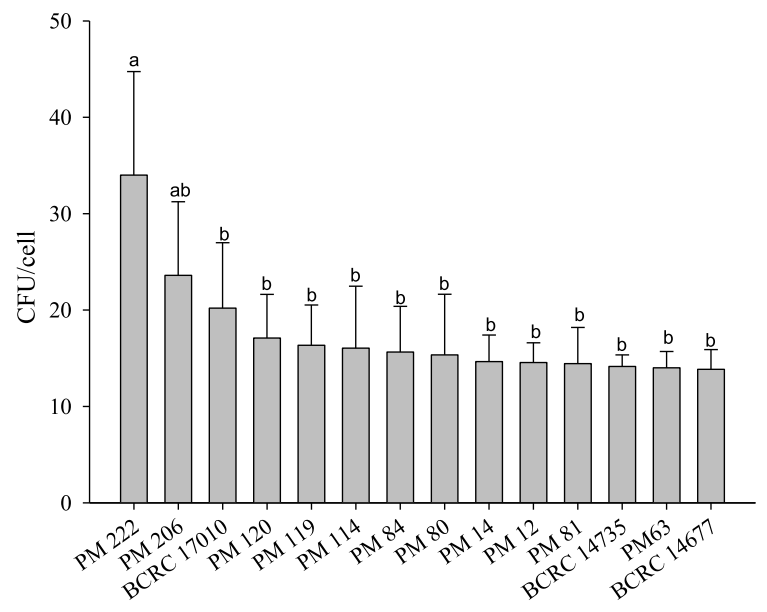

Fig. 1 Adhesion assays of 14 LAB on the Caco- 2 cells. Adhesion assays were monitored after $2 \mathrm{~h}$ of incubation. Ten of the Caco- 2 cells were used to calculate the average number of adhering LAB cells per epithelial cell. ${ }^{\mathrm{a}, \mathrm{b}}$ Values in the same column with different letters indicate significant difference $(p<0.05)$.

cells are widespread ${ }^{31}$ and serve as an excellent model for studying the biochemical processes of bacterial adherence and invasion by other cells ${ }^{29}$.

\section{LDH analysis}

Here, LAB and $V$. parahaemolyticus were co-cultured with Caco-2 intestinal epithelial cells to determine the activity of LDH and to observe whether V. para- 

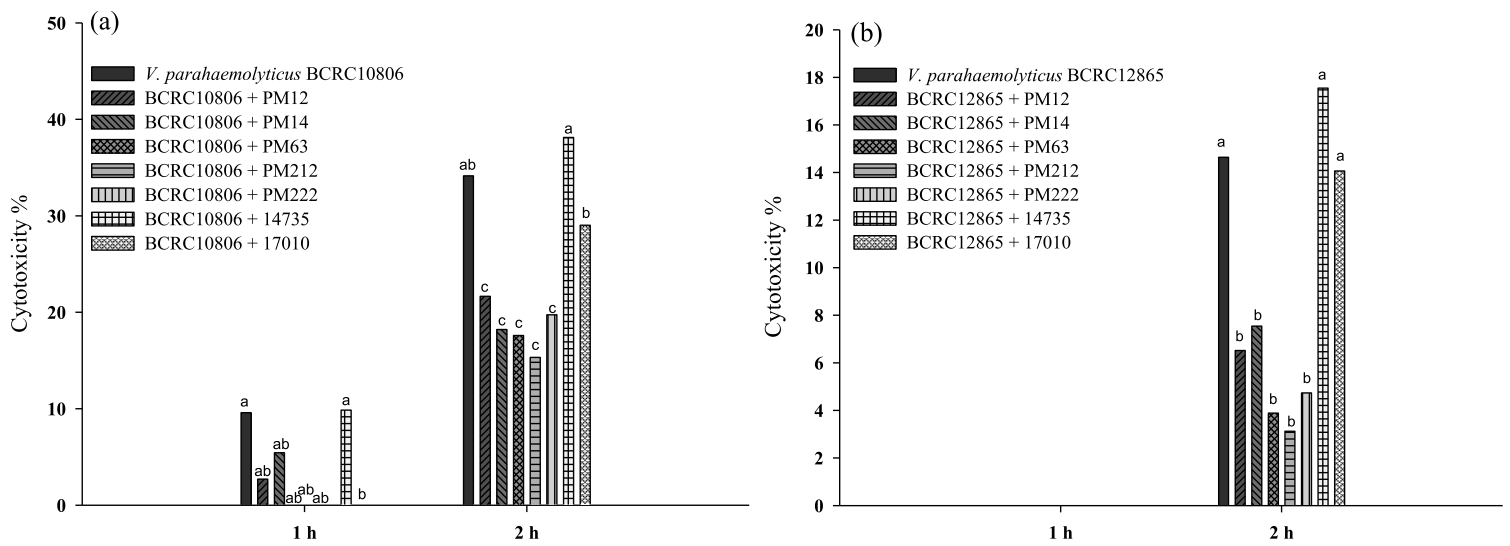

Fig. 2 Effect of $V$. parahaemolyticus (a) BCRC10806 and (b) BCRC12865 and LAB on Caco-2 cell cytotoxicity, assayed by $\mathrm{LDH}$ release. Each value is expressed as mean \pm SD of two replicate analyses. ${ }^{\mathrm{a}, \mathrm{b}}$ Means with different superscript letters in the same hour are significantly different $(p<0.05)$.

Table 2 Effect of heat treatment $\left(100^{\circ} \mathrm{C}, 15 \mathrm{~min}\right)$, dilution, and $\mathrm{pH} 7.2$ on the activity of cell free-spent culture supernatants (SCS) and viable cells of LAB against V. parahaemolyticus BCRC10806 or BCRC12865.

\begin{tabular}{|c|c|c|c|c|c|c|}
\hline \multirow{3}{*}{$\begin{array}{l}\text { V. para- } \\
\text { haemolyticus }\end{array}$} & \multirow{3}{*}{ LAB } & \multicolumn{5}{|c|}{ Inhibition zone $(\mathrm{mm})^{\dagger}$} \\
\hline & & \multirow{2}{*}{ Culture } & \multicolumn{2}{|c|}{$100^{\circ} \mathrm{C}, 15 \mathrm{~min}$} & \multirow{2}{*}{\multicolumn{2}{|c|}{ Dilution $\mathrm{pH} 7.2$}} \\
\hline & & & Culture & SCS & & \\
\hline \multirow[t]{15}{*}{ BCRC10806 } & PM12 & 13 & 11 & 9 & \multirow{15}{*}{$\leqslant 11$} & \multirow{15}{*}{$\leqslant 11$} \\
\hline & PM14 & 13 & 12 & 9 & & \\
\hline & PM63 & 13 & 11 & 12 & & \\
\hline & PM80 & 13 & 11 & 10 & & \\
\hline & PM81 & 12 & 12 & 11 & & \\
\hline & PM84 & 12 & 11 & 11 & & \\
\hline & PM114 & 12 & 12 & 9 & & \\
\hline & PM119 & 11 & 12 & 9 & & \\
\hline & PM120 & 12 & 12 & 9 & & \\
\hline & PM206 & 12 & 12 & 9 & & \\
\hline & PM212 & 12 & 15 & 9 & & \\
\hline & PM222 & 10 & 10 & 10 & & \\
\hline & 14677 & 9 & 9 & 9 & & \\
\hline & 14735 & 10 & 9 & 9 & & \\
\hline & 17010 & 13 & 12 & 10 & & \\
\hline \multirow[t]{15}{*}{ BCRC12865 } & PM12 & 12 & 10 & 9 & \multirow{15}{*}{$\leqslant 11$} & \multirow{15}{*}{$\leqslant 11$} \\
\hline & PM14 & 13 & 11 & 9 & & \\
\hline & PM63 & 12 & 11 & 11 & & \\
\hline & PM80 & 12 & 11 & 11 & & \\
\hline & PM81 & 12 & 12 & 11 & & \\
\hline & PM84 & 11 & 11 & 10 & & \\
\hline & PM114 & 12 & 11 & 9 & & \\
\hline & PM119 & 11 & 11 & 9 & & \\
\hline & PM120 & 12 & 12 & 9 & & \\
\hline & PM206 & 13 & 12 & 9 & & \\
\hline & PM212 & 12 & 11 & 9 & & \\
\hline & PM222 & 10 & 10 & 10 & & \\
\hline & 14677 & 9 & 9 & 9 & & \\
\hline & 14735 & 10 & 9 & 10 & & \\
\hline & 17010 & 13 & 12 & 11 & & \\
\hline
\end{tabular}

$\dagger$ The inhibition zone:,$- \leqslant 11 \mathrm{~mm} ;+, 12-16 \mathrm{~mm}$; ++, $17-22 \mathrm{~mm}$; and,$+++ \geqslant 23 \mathrm{~mm}$.

haemolyticus would damage Caco-2 cells or LAB could reduce this damage. We found that V. para-
Table 3 The survival of $V$. parahaemolyticus BCRC10806 or BCRC12865 in co-culture with LAB!

\begin{tabular}{|c|c|c|c|c|c|}
\hline Survival (\%) & LAB & $1 \mathrm{~h}$ & $2 \mathrm{~h}$ & $3 \mathrm{~h}$ & $4 \mathrm{~h}$ \\
\hline \multirow[t]{14}{*}{ BCRC10806 } & 14677 & $34.80^{\mathrm{Aa}}$ & $0.57^{\mathrm{Ab}}$ & $<0.01^{\mathrm{Ac}}$ & $<0.01^{\mathrm{c}}$ \\
\hline & 14735 & $22.45^{\mathrm{Aa}}$ & $6.55^{\mathrm{Ab}}$ & $<0.01^{\mathrm{Ac}}$ & $<0.01^{\mathrm{c}}$ \\
\hline & 17010 & $60.27^{\mathrm{Aa}}$ & $0.19^{\mathrm{Ab}}$ & $<0.01^{\mathrm{Ab}}$ & $<0.01^{b}$ \\
\hline & PM14 & $48.56^{\mathrm{Aa}}$ & $0.65^{\mathrm{Ab}}$ & $<0.01^{\mathrm{Ac}}$ & $<0.01^{\mathrm{c}}$ \\
\hline & PM63 & $35.50^{\mathrm{Aa}}$ & $0.85^{\mathrm{Ab}}$ & $<0.01^{\mathrm{Ac}}$ & $<0.01^{\mathrm{c}}$ \\
\hline & PM80 & $142.37^{\mathrm{Ba}}$ & $1.66^{\mathrm{Ab}}$ & $<0.01^{\mathrm{Ac}}$ & $<0.01^{\mathrm{c}}$ \\
\hline & PM81 & $159.96^{\mathrm{Ba}}$ & $2.26^{\mathrm{Ab}}$ & $<0.01^{\mathrm{Ac}}$ & $<0.01^{\mathrm{c}}$ \\
\hline & PM84 & $20.64^{\mathrm{Aa}}$ & $0.03^{\mathrm{Ab}}$ & $<0.01^{\mathrm{Ab}}$ & $<0.01^{\text {b }}$ \\
\hline & PM114 & $45.21^{\mathrm{Aa}}$ & $0.37^{\mathrm{Ab}}$ & $<0.01^{\mathrm{Ab}}$ & $<0.01^{\text {b }}$ \\
\hline & PM119 & $119.92^{\mathrm{Ba}}$ & $1.71^{\mathrm{Ab}}$ & $<0.01^{\mathrm{Ac}}$ & $<0.01^{\mathrm{c}}$ \\
\hline & PM120 & $192.38^{\mathrm{Ba}}$ & $1.16^{\mathrm{Ab}}$ & $<0.01^{\mathrm{Ac}}$ & $<0.01^{\mathrm{c}}$ \\
\hline & PM206 & $166.73^{\mathrm{Ba}}$ & $0.34^{\mathrm{Ab}}$ & $<0.01^{\mathrm{Ab}}$ & $<0.01^{\mathrm{b}}$ \\
\hline & PM212 & $27.15^{\mathrm{Aa}}$ & $1.18^{\mathrm{Ab}}$ & $0.01^{\mathrm{Ac}}$ & $<0.01^{c}$ \\
\hline & PM222 & $181.14^{\mathrm{Ba}}$ & $43.11^{\mathrm{Bb}}$ & $0.55^{\mathrm{BC}}$ & $<0.01^{\mathrm{d}}$ \\
\hline \multirow[t]{15}{*}{ BCRC12865 } & 14677 & $15.07^{\mathrm{Aa}}$ & $0.55^{\mathrm{Ab}}$ & $<0.01^{\mathrm{Ac}}$ & $<0.01^{\mathrm{c}}$ \\
\hline & 14735 & $74.71^{\mathrm{Aa}}$ & $1.98^{\mathrm{Ab}}$ & $0.49^{\mathrm{BC}}$ & $<0.01^{\mathrm{c}}$ \\
\hline & 17010 & $12.64^{\mathrm{Aa}}$ & $0.30^{\mathrm{Ab}}$ & $<0.01^{\mathrm{Ab}}$ & $<0.01^{\mathrm{b}}$ \\
\hline & PM12 & $31.62^{\mathrm{Aa}}$ & $1.63^{\mathrm{Ab}}$ & $<0.01^{\mathrm{Ac}}$ & $<0.01^{\mathrm{c}}$ \\
\hline & $\begin{array}{l}\text { PM14 } \\
\text { PM }\end{array}$ & $12.24^{\mathrm{Aa}}$ & $2.09^{\mathrm{Ab}}$ & $<0.01^{\mathrm{Ac}}$ & $<0.01^{\mathrm{c}}$ \\
\hline & PM63 & $59.74^{\mathrm{Aa}}$ & $0.39^{\mathrm{Ab}}$ & $<0.01^{\mathrm{Ab}}$ & $<0.01^{b}$ \\
\hline & PM80 & 66.77 & $4.01^{\mathrm{Ab}}$ & $<0.01^{\mathrm{Ac}}$ & $<0.01^{\mathrm{c}}$ \\
\hline & PM81 & $71.78^{\mathrm{Aa}}$ & $1.63^{\mathrm{Ab}}$ & $<0.01^{\mathrm{Ac}}$ & $<0.01^{\mathrm{c}}$ \\
\hline & PM84 & $46.72^{\mathrm{Aa}}$ & $0.63^{\mathrm{Ab}}$ & $<0.01^{\mathrm{Ac}}$ & $<0.01^{\mathrm{c}}$ \\
\hline & PM114 & $60.79^{\mathrm{Aa}}$ & $2.74^{\mathrm{Ab}}$ & $<0.01^{\mathrm{Ab}}$ & $<0.01^{\mathrm{c}}$ \\
\hline & PM119 & $14.27^{\mathrm{Aa}}$ & $0.37^{\mathrm{Ab}}$ & $<0.01^{\mathrm{Ac}}$ & $<0.01^{\text {b }}$ \\
\hline & PM120 & $32.71^{\mathrm{Aa}}$ & $0.10^{\mathrm{Ab}}$ & $<0.01^{\mathrm{Ab}}$ & $<0.01^{\text {b }}$ \\
\hline & PM206 & $19.48^{\mathrm{Aa}}$ & $0.17^{\mathrm{Ab}}$ & $<0.01^{\mathrm{Ab}}$ & $<0.01^{\mathrm{b}}$ \\
\hline & PM212 & $49.80^{\mathrm{Aa}}$ & $1.80^{\mathrm{Ab}}$ & $0.01^{\mathrm{Ac}}$ & $<0.01^{\mathrm{c}}$ \\
\hline & PM222 & $178.95^{\mathrm{Ba}}$ & $28.83^{\mathrm{Bb}}$ & $0.03^{\mathrm{Ac}}$ & $<0.01^{\mathrm{c}}$ \\
\hline
\end{tabular}

$\dagger \mathrm{A}, \mathrm{B}$ Values in the same column with different letters indicate significant difference $(p<0.05)$. ${ }^{\text {a,b,c,d }}$ Values in the same row with different letters indicate significant difference $(p<0.05)$.

haemolyticus BCRC10806 induced only a slight injury in cells, with cytotoxic activity of approximately $9.59 \%$ when incubated for $1 \mathrm{~h}$ (Fig. 2); after $2 \mathrm{~h}$, the cytotoxicity of $V$. parahaemolyticus BCRC10806 and BCRC12865 was found to be $34.15 \%$ and $14.64 \%$, 
Table 4 Effect of inhibitory activity against $V$. parahaemolyticus by antimicrobial disc.

\begin{tabular}{lrr}
\hline \multirow{2}{*}{ Antimicrobial disc } & \multicolumn{2}{c}{ Inhibition zone (mm) } \\
\cline { 2 - 3 } & BCRC10806 & BCRC12865 \\
\hline Ampicillin $(10 \mu \mathrm{g})$ & $7.5 \pm 0.7$ & $9.0 \pm 0.0$ \\
Kanamycin $(30 \mu \mathrm{g})$ & $17.0 \pm 1.4$ & $18.5 \pm 0.7$ \\
Tetracycline $(30 \mu \mathrm{g})$ & $23.0 \pm 2.8$ & $21.5 \pm 0.7$ \\
Penicillin G $(10 \mu \mathrm{g})$ & $6.0 \pm 0.0$ & $7.0 \pm 1.4$ \\
Neomycin $(30 \mu \mathrm{g})$ & $16.0 \pm 1.4$ & $16.0 \pm 1.4$ \\
Erythromycin $(15 \mu \mathrm{g})$ & $18.0 \pm 0.0$ & $13.0 \pm 1.4$ \\
Streptomycin $(10 \mu \mathrm{g})$ & $12.5 \pm 0.7$ & $12.5 \pm 0.7$ \\
Gentamicin $(30 \mu \mathrm{g})$ & $19.5 \pm 0.7$ & $19.0 \pm 1.4$ \\
Chloramphenicol $(30 \mu \mathrm{g})$ & $28.0 \pm 1.4$ & $26.0 \pm 1.4$ \\
Spiramycin $(100 \mu \mathrm{g})$ & $16.5 \pm 0.7$ & $12.0 \pm 2.8$ \\
\hline
\end{tabular}

respectively (Fig. 1), indicating that the two Vibrio strains grew with time and gradually induced cell damage.

Matlawska-Wasowska et $\mathrm{al}^{20}$ tested the cytotoxicity of $V$. parahaemolyticus on epithelial cells. They reported no cell lysis before $2 \mathrm{~h}$; however, cell lysis increased with time (from 3-4 h). Fernández et $\mathrm{al}^{32}$ also reported that $V$. parahaemolyticus was cytotoxic to Caco-2 epithelial cells in a timedependent manner; cell lysis increased in 3 or $4 \mathrm{~h}$ later. Similarly, the amount of cell lysis was found to be time-dependent in this study: when LAB and $V$. parahaemolyticus were co-cultured with the Caco-2 intestinal epithelial cell line (Fig. 2), 5 LAB (PM12, PM14, PM63, PM212, and PM222) reduced the damage caused by Vibrio spp. to the Caco-2 cells.

\section{Competitive adherence between LAB and V. parahaemolyticus}

As shown in Table 5, seven LAB competitively adhered to the Caco-2 intestinal epithelial cells with $V$. parahaemolyticus BCRC10806. The prevention group and the simultaneous action revealed a significant decrease in the residual rate of $V$. parahaemolyticus as compared with that of the control group, and the prevention of $V$. parahaemolyticus survival rate was less than $10 \%$. Seven LAB strains competitively adhered to the Caco-2 intestinal epithelial cells with V. parahaemolyticus BCRC12865 (Table 5), and the residual ratio of $V$. intestinalis was significantly reduced (1-25\%) in the prevention group as compared with that in the control group. Based on the above results, we concluded that LAB preferentially inhibited the competitive adherence of both strains of $V$. parahaemolyticus, suggesting that LAB has a preventive effect. Here, strain BCRC17010 was found to be the best for inhibition.

The adherence of pathogenic bacteria onto the intestinal mucosal surface is considered the first step in intestinal tract infection ${ }^{33}$. Therefore, inhibiting pathogen adherence can prevent the infection and colonization of the intestine ${ }^{34}$. Probiotics can inhibit pathogenic bacteria through competitive repulsion and antagonism to maintain a healthy gut flora ${ }^{35}$. Numerous in vitro tests have demonstrated that LAB can inhibit pathogen adherence or invasion into intestinal cells ${ }^{36-38}$. According to literature, L. plantarum AS1 was inhibitory to V. parahaemolyticus during adhesion of the HT-29 cell line ${ }^{12}$. Lactobacilli were implicated as a physical barrier to inhibit direct contact with epithelial cells via competitive exclusion, and bacteriocin of lactobacilli also was suggested to exhibit a direct inhibitory effect on the pathogen's adherence to epithelial cells ${ }^{39}$.

\section{$\mathrm{LAB}$ inhibition on the invasion of V. parahaemolyticus in Caco-2 intestinal epithelial cells}

Invasive pathogens can break through the host mucosal barrier, thereby invading and colonizing it to cause intestinal diseases ${ }^{40,41}$. Some studies have shown that diseases are caused by Vibrio spp. not only because of the toxins they produce but also because of their invasion into the gut epithelium ${ }^{6}$. Therefore, we examined whether LAB could inhibit the invasion of Caco-2 cells by $V$. parahaemolyticus. We found that 7 LAB (PM12, PM14, PM63, PM212, PM222, BCRC14735, and BCRC17010) inhibited this invasion. The inhibitory effect was greater for the invasion by $V$. parahaemolyticus BCRC12865 than for that by $V$. parahaemolyticus BCRC10806 (Table 6). In literature, the L. acidophilus had the potential to bind to epithelial cell brush borders by calcium cations acting as an ion bridge ${ }^{39}$. LAB can inhibit the pathogen attachment via the steric hindrance mechanism ${ }^{12}$. The invasion and adherence of $V$. cholerae to Caco- 2 cells was reduced by L. acidophilus ${ }^{39}$.

\section{CONCLUSION}

In conclusion, $\mathrm{LAB}$ from this study can inhibit the growth of $V$. parahaemolyticus. The LDH assay revealed that certain LAB could significantly decrease the cytotoxicity induced by both $V$. parahaemolyticus BCRC10806 and BCRC12865 strains after a 2 hincubation. In the competition adherence assay, the prevention group revealed inhibitory effects against 
Table 5 Effect of LAB on the survival of V. parahaemolyticus BCRC10806 or BCRC12865 from colonizing Caco-2 cells.

\begin{tabular}{|c|c|c|c|c|c|c|c|}
\hline \multirow{2}{*}{ V. parahaemolyticus } & \multirow{2}{*}{$\mathrm{LAB}$} & \multicolumn{2}{|c|}{ Prevention } & \multicolumn{2}{|c|}{ Treatment } & \multicolumn{2}{|c|}{ Competition } \\
\hline & & $\log \mathrm{CFU} / \mathrm{ml}$ & $\%$ & $\log \mathrm{CFU} / \mathrm{ml}$ & $\%$ & $\log \mathrm{CFU} / \mathrm{ml}$ & $\%$ \\
\hline \multirow[t]{8}{*}{ BCRC10806 } & Control $^{*}$ & $4.77 \pm 0.70$ & 100 & $4.41 \pm 0.40$ & 100 & $4.01 \pm 0.62$ & 100 \\
\hline & PM12 & $3.51 \pm 1.19$ & 5.40 & $3.87 \pm 0.74$ & 28.74 & $2.32 \pm 0.21$ & 2.01 \\
\hline & PM14 & $3.40 \pm 0.84$ & 4.19 & $4.37 \pm 0.70$ & 91.46 & $2.14 \pm 0.08$ & 1.33 \\
\hline & PM63 & $3.38 \pm 1.01$ & 4.02 & $4.21 \pm 2.15$ & 62.97 & $2.35 \pm 0.17$ & 2.18 \\
\hline & PM212 & $3.68 \pm 0.03$ & 8.02 & $4.03 \pm 1.50$ & 42.36 & $1.98 \pm 0.13$ & 0.92 \\
\hline & PM222 & $3.09 \pm 0.08$ & 2.09 & $4.01 \pm 1.28$ & 39.70 & $2.62 \pm 0.00$ & 4.00 \\
\hline & 14735 & $2.51 \pm 0.38$ & 0.54 & $3.95 \pm 1.21$ & 34.88 & $3.50 \pm 0.85$ & 30.52 \\
\hline & 17010 & $2.88 \pm 0.07$ & 1.27 & $4.10 \pm 1.49$ & 49.06 & $2.66 \pm 0.77$ & 4.46 \\
\hline \multirow[t]{8}{*}{ BCRC12865 } & Control $^{*}$ & $4.87 \pm 0.32$ & 100 & $5.55 \pm 0.44$ & 100 & $4.29 \pm 1.62$ & 100 \\
\hline & PM12 & $4.12 \pm 0.76$ & 17.83 & $4.98 \pm 0.03$ & 26.91 & $3.60 \pm 0.62$ & 20.54 \\
\hline & PM14 & $3.94 \pm 0.50$ & 11.64 & $5.20 \pm 0.22$ & 45.04 & $3.97 \pm 1.14$ & 48.09 \\
\hline & PM63 & $4.29 \pm 0.87$ & 25.92 & $4.98 \pm 0.10$ & 27.20 & $3.96 \pm 1.86$ & 46.28 \\
\hline & PM212 & $4.02 \pm 0.36$ & 13.97 & $4.96 \pm 0.03$ & 25.92 & $4.21 \pm 2.12$ & 83.25 \\
\hline & PM222 & $3.38 \pm 0.09$ & 3.19 & $5.13 \pm 0.22$ & 38.10 & $4.25 \pm 2.26$ & 90.62 \\
\hline & 14735 & $3.60 \pm 0.09$ & 5.31 & $5.52 \pm 0.13$ & 93.06 & $3.24 \pm 1.25$ & 8.82 \\
\hline & 17010 & $2.95 \pm 0.26$ & 1.20 & $5.28 \pm 0.03$ & 54.25 & $3.41 \pm 1.64$ & 13.20 \\
\hline
\end{tabular}

* Control: $900 \mu \mathrm{l}$ of fresh medium and $100 \mu \mathrm{l}$. parahaemolyticus $\left(10^{7} \mathrm{CFU} / \mathrm{ml}\right)$

Table 6 Effect of LAB on the invasion of the Caco-2 cell line by V. parahaemolyticus BCRC12865!

\begin{tabular}{llcc}
\hline V. parahaemolyticus & LAB & $\begin{array}{c}\text { Invasion } \\
(\log \text { CFU/ml) }\end{array}$ & $\begin{array}{c}\text { Inhibition } \\
(\%)\end{array}$ \\
\hline BCRC10806 & Control $^{*}$ & $2.24 \pm 0.18$ & 0 \\
& PM12 & $1.77 \pm 0.95$ & 34.99 \\
& PM14 & $1.53 \pm 0.72$ & 72.31 \\
& PM63 & $1.86 \pm 0.75$ & 39.25 \\
& PM212 & $1.71 \pm 1.06$ & 34.72 \\
& PM222 & $1.73 \pm 0.93$ & 43.88 \\
& 14735 & $1.62 \pm 0.36$ & 74.95 \\
BCRC12865 & Control & $3.57 \pm 0.94$ & 0 \\
& PM12 & $2.20 \pm 0.28$ & 93.10 \\
& PM14 & $2.24 \pm 0.41$ & 93.46 \\
& PM63 & $2.13 \pm 0.07$ & 92.15 \\
& PM212 & $2.02 \pm 0.55$ & 83.98 \\
& PM222 & $2.01 \pm 0.62$ & 82.61 \\
& 14735 & $1.80 \pm 0.32$ & 93.25 \\
& 17010 & $1.56 \pm 0.45$ & 95.32 \\
\hline
\end{tabular}

$\dagger$ The number of $V$. parahaemolyticus BCRC12865 before the invasion is $7.64 \log \mathrm{CFU} / \mathrm{ml}$.

* Control: $900 \mu \mathrm{l}$ of fresh medium and $100 \mu \mathrm{l}$. parahaemolyticus $\left(10^{7} \mathrm{CFU} / \mathrm{ml}\right)$

the two V. parahaemolyticus strains. Besides, we revealed that the LAB inhibited $V$. parahaemolyticus invasion of Caco-2 cells. The mechanism of LAB against $V$. parahaemolyticus will be explored in near future.
Acknowledgements: This study was funded by the MOST 102-2313-B-241-001-MY3 project from Ministry of Science and Technology, and the Higher Education Sprout Project, Ministry of Education, Taiwan.

\section{REFERENCES}

1. Desmarchelier PM (1997) Pathogenic Vibrios. In: Hocking AD, Arnold G, Jenson I, Newton K, Sutherland P (eds) Foodborne Microorganisms of Public Health Significance, 5th edn, Australian Institute of Food Science \& Technology, Sydney, pp 285-312.

2. Ministry of Health, Labour \& Welfare (2000) Statistics of Food Poisoning Japan in 2000, Ministry of Health, Labour \& Welfare, Japan.

3. Kodama T, Hiyoshi H, Gotoh K, Akeda Y, Matsuda S, Park KS, Cantarelli VV, Iida T, et al (2008) Identification of two translocon proteins of Virbo parahaemolyticus type III secretion system 2 . Infect Immun 76, 4282-4289.

4. Park KS, Ono T, Rokuda M, Jang MH, Okada K, Iida T, Honda T (2004) Functional characterization of two type III secretion systems of Virbo parahaemolyticus. Infect Immun 72, 6659-6665.

5. Zhang L, Krachler AM, Broberg CA, Li Y, Mirzaei H, Gilpin CJ, Orth K (2012) Type III effector VopC mediates invasion for Vibrio species. Cell Rep 1, 453-460.

6. Akeda Y, Nagayama K, Yamamoto K, Honda T (1997) Invasive phenotype of Vibrio parahaemolyticus. J Infect Dis 176, 822-824.

7. Akeda Y, Kodama T, Kashimoto T, Cantarelli V, Horiguchi Y, Nagayama K, Iida T, Honda T (2002) Dominant-negative Rho, Rac, and Cdc42 facilitate 
the invasion process of Vibrio parahaemolyticus into Caco- 2 cells. Infect Immun 70, 970-973.

8. Yeung PS, Boor KJ (2004) Epidemiology, pathogenesis, and prevention of foodborne Vibrio parahaemolyticus infections. Foodborne Pathog Dis 1, 74-88.

9. Shimohata T, Takahashi A (2010) Diarrhea induced by infection of Vibrio parahaemolyticus. J Med Invest 57, 179-182.

10. Broberg CA, Calder TJ, Orth K (2011) Vibrio parahaemolyticus cell biology and pathogenicity determinants. Microbes Infect 13, 992-1001.

11. Nair GB, Ramamurthy T, Bhattacharya SK, Dutta B, Takeda Y, Sack DA (2007) Global dissemination of Vibrio parahaemolyticus serotype 03:K6 and its serovariants. Clin Microbiol Rev 20, 39-48.

12. Satish Kumar R, Kanmani P, Yuvaraj N, Paari KA, Pattukumar V, Arul V (2011) Lactobacillus plantarum AS1 binds to cultured human intestinal cell line HT29 and inhibits cell attachment by enterovirulent bacterium Vibrio parahaemolyticus. Lett Appl Microbiol 53, 481-487.

13. Yang ZQ, Jin CJ, Gao L, Fang WM, Gu RX, Qian JY, Jiao XA (2013) Alleviating effects of Lactobacillus strains on pathogenic Vibrio parahaemolyticusinduced intestinal fluid accumulation in the mouse model. FEMS Microbiol Lett 339, 30-38.

14. Le B, Yang SH (2018) Probiotic potential of novel Lactobacillus strains isolated from salted-fermented shrimp as antagonists for Vibrio parahaemolyticus. $J$ Microbiol 56, 138-144.

15. Shirazinejad A, Ismail N, Bhat R (2010) Lactic acid as a potential decontaminant of selected foodborne pathogenic bacteria in shrimp (Penaeus merguiensis de Man). Foodborne Pathog Dis 7, 1531-1536.

16. Lin TH, Pan TM (2019) Characterization of an antimicrobial substance produced by Lactobacillus plantarum NTU 102. J Microbiol Immunol Infec 52, 409-417.

17. Rammelsberg M, Radler F (1990) Antibacterial polypeptides of Lactobacillus species. J Appl Bacteriol 69, 177-184

18. Varma P, Dinesh KR, Menon KK, Biswas R (2010) Lactobacillus fermentum isolated from human colonic mucosal biopsy inhibits the growth and adhesion of enteric and foodborne pathogens. J Food Sci 75, 546-551.

19. Gueimonde M, Jalonen L, He F, Hiramatsu M, Salminen S (2006) Adhesion and competitive inhibition and displacement of human enteropathogens by selected lactobacilli. Food Res Int 39, 467-471.

20. Matlawska-Wasowska K, Finn R, Mustel A, O’Byrne CP, Baird AW, Coffey ET, Boyd A (2010) The Vibrio parahaemolyticus Type III Secretion Systems manipulate host cell MAPK for critical steps in pathogenesis. BMC Microbiol 10, ID 329.

21. Tsai CC, Hung YH, Chou LC (2018) Evaluation of lactic acid bacteria on the inhibition of Vibrio parahaemolyticus infection and its application to food systems. Molecules 23, ID 1238.

22. Hirano J, Yoshida T, Sugiyama T, Koide N, Mori I, Yokochi T (2003) The effect of Lactobacillus rhamnosus on enterochemorrhagic Escherichia coli infection of human intestinal cells in vitro. Microbiol Immun 47, 405-409.

23. Gopal PK, Prasad J, Smart J, Gill HS (2001) In vitro adherence properties of Lactobacillus rhamnosus DR20 and Bifidobacterium lactis DR10 strains and their antagonistic activity against an enterotoxigenic Escherichia coli. Int J Food Microbiol 67, 207-216.

24. Kaur S, Sharma P, Kalia N, Singh J, Kaur S (2018) Anti-biofilm properties of the fecal probiotic lactobacilli against Vibrio spp. Front Cell Infect Microbiol 8, ID 120.

25. Hwanhlem N, Watthanasakphuban N, Riebroy S, Benjakul S, Maneerat S (2010) Probiotic lactic acid bacteria from Kung-Som: Isolation, screening, inhibition of pathogenic bacteria. Int $J$ Food Sci 45, 594-601.

26. Sahandi J, Sorgeloos P, Xiao H, Wang X, Qi Z, Zheng Y, Tang X (2019) The use of selected bacteria and yeasts to control Vibrio spp. in live food. Antibiotics 8, ID 95.

27. Pedersen K, Tannock GW (1989) Colonization of the porcine gastrointestinal tract by lactobacilli. Appl Environ Microbiol 55, 279-283.

28. Tuomola EM, Salminen SJ (1998) Adhesion of some probiotic and dairy Lactobacillus strains to Caco-2 cell cultures. Int J Food Microbiol 41, 45-51.

29. Chauviere G, Coconnier MH, Kerneis S, DarfeuilleMichaud A, Joly B, Servin AL (1992) Competitive exclusion of diarrheagenic Escherichia coli (EHEC) from enterocyte-like Caco-2 cells in culture. FEMS Microbiol Lett 91, 213-217.

30. Hauri HP, Sterchi EE, Bienz D, Fransen JAM, Marxer A (1985) Expression and intracellular transport to microvillus membrane hydrolases in human intestinal epithelial cells. J Cell Biol 101, 838-851.

31. Zweibaum A, Laburthe M, Grasset E, Louvard D (1991) Use of cultured cell lines in studies of intestinal cell differentiation and function. In: The Gastrointestinal System IV, pp 223-225.

32. Fernández MF, Boris S, Barbes C (2003) Probiotic properties of human lactobacilli strains to be used in the gastrointestinal tract. J Appl Microbiol 94, 449-455.

33. Finlay BB, Falkow S (1997) Common themes in microbial pathogenicity revisited. Microbiol Mol Biol Rev 61, 136-169.

34. Tuomola EM, Ouwehand AC, Salminen SJ (1999) The effect of probiotic bacteria on the adhesion of pathogens to human intestinal mucus. FEMS Immunol Med Microbiol 26, 137-142.

35. Fuller R (1989) Probiotics in man and animals. J Appl 
Bacteriol 66, 365-378.

36. Lee YK, Lim CY, Teng WL, Ouwehand AC, Tuomola EM, Salminen S (2000) Quantitative approach in the study of adhesion of lactic acid bacteria to intestinal cells and their competition with enterobacteria. Appl Environ Microbiol 66, 3692-3697.

37. Fujiwara S, Hashiba H, Hirota T, Forstner JF (2001) Inhibition of the binding of enterotoxigenic Escherichia coli $\mathrm{Pb} 176$ to human intestinal epithelial cell line HCT-8 by an extracellular protein faction containing BIF of Bifidobacterium longum SBT2928: suggestive evidence of blocking of the binding receptor ganglioteraosylceramide on the cell surface. Int $J$ Food Microbiol 67, 97-106.

38. Gagnon M, Kheadr EE, Blay GL, Fliss I (2004) In vitro inhibition of Escherichia coli O157:H7 by bifidobacterial strains of human origin. Int J Food Microbiol 92,
69-78.

39. Alamdary SZ, Bakhshi B, Soudi S (2018) The antiapoptotic and anti-inflammatory effect of Lactobacillus acidophilus on Shigella sonnei and Vibrio cholerae interaction with intestinal epithelial cells: A comparison between invasive and non-invasive bacteria. PLoS One 13, ID e0196941.

40. Ford HR, Avanoglu A, Boechat PR, Melgoza R, LumCheong RS, Boyle P, Garrett M, Rowe MI (1996) The microenvironment influences the pattern of bacterial translocation in formula-fed neonates. J Pediatr Surg 31, 486-489.

41. Urao M, Teitelbaum DH, Drongowski RA, Coran AG (1996) The association of gut-associated lymphoid tissue and bacterial translocation in the newborn rabbit. J Pediatr Surg 31, 1482-1487. 